\title{
MEZI GÉNIEM A SVĚTCEM: DEKONSTRUKCE NEJEDLÉHO KONCEPCE VELKÉHO ČESKÉHO SKLADATELE
}

Nebývá dostatečně zdo̊razňováno, že Zdeněk Nejedlý byl jediným českým muzikologem nebo hudebním kritikem období vzniku a rozvoje moderní české hudby (cca 1860-1918), který vytvořil komplexní a koherentní koncepci dějin tohoto procesu. ${ }^{1}$ Slovem komplexni rozumím skutečnost, že tato koncepce ve své šíři zahrnovala, hodnotila a ,vysvětlovala“ všechny důležité skladatelské osobnosti daného období, slovem koherentní pak vyjadřuji její vnitřní jednotu a soudržnost, jež zůstávala v základních rysech zachována př̀i jejích dílčích konkretizacích.

Nejdůležitější Nejedlého publikace z období 1901-1921 věnované dějinám moderní české hudby můžeme rozdělit do dvou skupin podle toho, zda se zabývají všeobecnými dějinami české moderní hudby, nebo konkrétními skladateli. První skupina zahrnuje Dějiny české hudby, ${ }^{2}$ soubor popularizačních přednášek Česká moderní zpěvohra po Smetanovi ${ }^{3}$ a částečně také esej Slovanská hudba. ${ }^{4}$ Druhá, obsáhlejší skupina sestává z dalšího souboru popularizačních přednášek, navazujícího na prvý zmíněný - Zpěvoher Smetanových, ${ }^{5}$ kolekce smetanovských esejí vydaných pod názvem Smetaniana, ${ }^{6}$ dále dvou monografií Zdenko

$1 \quad$ K Nejedlého př́stupu k muzikologii a jeho filosofickým a historiografickým východiskům viz zejm. STŘÍTECKÝ, Jaroslav - HANZAL, Josef. Předmluva. In Zdeněk Nejedlý. Umění staré a nové: Výbor ze studii. Praha: Editio Supraphon, 1978, s. 5-37; LÉBL, Vladimír POLEDŇÁK, Ivan (eds.). Hudebni věda: Historie a teorie oboru, jeho světový a český vývoj - 1. díl. Praha: Státní pedagogické nakladatelství, 1988, s. 172-182. Srov. též RANSDORF, Miloslav. Zdeněk Nejedlý. Praha: Horizont, 1988; KŘESŤAN, Zdeněk. Pojetí české otázky $v$ dile Zdeňka Nejedlého. Praha: Státní úřední archiv, 1996.

NEJEDLÝ, Zdeněk. Dějiny české hudby. Praha: Hejda a Tuček, 1903.

3 NEJEDLÝ, Zdeněk. Česká moderní zpěvohra po Smetanovi: kurs šestnáctipřednáškový. Praha: J. Otto, 1911.

4 NEJEDLÝ, Zdeněk. Slovanská hudba. In Slovanstvo: obraz jeho minulosti a přitomnosti. Jaroslav Bidlo (ed.). Praha: J. Laichter, 1912, s. 606-626.

5 NEJEDLÝ, Zdeněk. Zpěvohry Smetanovy. Praha: J. Otto, 1908.

6 NEJEDLÝ, Zdeněk. Smetaniana. Praha: Melantrich, 1922. 
Fibich. Zakladatel scénického melodramatu ${ }^{7}$ a Jos. B. Foerster ${ }^{8}$ dvou krátkých, avšak významných článků o Antonínu Dvořákovi, z nichž první vyšel jako nekrolog těsně po Dvořákově smrti, druhý o devět let později, ${ }^{9}$ a sbírky novákovských esejí a kritik, publikované pod názvem Vitězslav Novák. ${ }^{10}$

Na základě narativní a diskurzivní analýzy zmíněných textů jsem dekonstruoval Nejedlého koncepci dějin moderní české hudby a následně odhalit konceptuální model v jejím pozadí, tedy její skryté apriorní předpoklady, jakož i hlubinné narativní a tropologické vzorce, což mi umožnilo vysvětlit rétorický a narativní mechanismus Nejedlého zmíněných textů a způsoby, jakými dosahovaly kýženého efektu věrohodnosti.

Vycházeje z teoretického př́stupu známého jako metahistorická analýza, vyvinutého Haydenem Whitem primárně pro analýzu imaginativních modelů zásadních historiografických koncepcí 19. století, ${ }^{11}$ snažil jsem se odhalit obdobný imaginativní model „V pozadí (nebo spíše „, hlubinách“) narativu produkovaném sumou zmíněných Nejedlého textů. ${ }^{12}$ Podle Whitea je funkcí takovéto skryté narativní struktury zdůvěryhodnění dané reprezentace historického pole. Podvědomým ztotožněním archetypálního, mytologického vzorce „v pozadí“ historiografického narativu získává čtenář citový vztah $\mathrm{k}$ danému výkladu dějin a snáz podléhá jeho ideologickým silám.

V této studii není dost prostoru pro detailní analýzu Nejedlého výkladu; ${ }^{13}$ omezím se proto pouze na konstatování, že existují tři úrovně Nejedlého konceptualizace dějin moderní české hudby (které iniciují tř̌i různá čtení), a vysvětlení

7 NEJEDLÝ, Zdeněk. Zdenko Fibich. Zakladatel scénického melodramatu. Praha: Hejda a Tuček, 1901.

8 NEJEDLÝ, Zdeněk. Jos. B. Foerster. Praha: Komorní hudební závod Mojmíra Urbánka, 1910.

9 NEJEDLÝ, Zdeněk. Antonín Dvořák mrtev. Zvon, 1904, roč. 4, č. 33, s. 464; NEJEDLÝ, Zdeněk. „Boj“ proti Ant. Dvořákovi. Česká kultura, 1912/1913, roč. 1, č. 6, s. 187. Beru také v potaz Nejedlého polemický text o Karlu Knittlovi: NEJEDLÝ, Zdeněk. Ke sporu o K. Knittla: na obranu K. Steckerovi. Praha: Jos. Pávek, 1907.

10 NEJEDLÝ, Zdeněk. Vitězslav Novák. Studie a kritiky. Praha: Melantrich, 1921.

11 WHITE, Hayden. Metahistory. The Historical Imagination in Nineteenth-Century Europe. Baltimore: Johns Hopkins University Press, 1973; WHITE, Hayden. Tropics of Discourse: Essays in Cultural Criticism. Baltimore: Johns Hopkins University Press, 1978. Třicet let diskusí o Whiteově př́stupu sumarizoval mj. Čornej, viz ČORNEJ, Petr. White nezměnil dějiny, ale pohled na ně. In Hayden White. Metahistorie. Historická imaginace v Evropě devatenáctého století. Brno: Host, 2011, s. 575-600.

12 Dosud byly - pokud vím - učiněny tři významné pokusy aplikovat metahistorický př́stup na analýzu českého dějepiseckého myšlení: ǨEPA, Milan. Poetika českého dějepisectví. Brno: Host, 2006. FEUEREIS, Eduard. Narativismus a historiografie. Dějiny - teorie - kritika, 2011, roč. 8, č. 1, s. 7-34. ČINÁTL, Kamil. Dějiny a vyprávění. Palackého dějiny jako zdroj historické obraznosti národa. Praha: Argo, 2011. Je překvapivé, že Řepa nezahrnul Nejedlého do své analýzy literárního stylu hlavních postav českého dějepisectví.

13 Tu podávám ve studii From tragedy to romance, from positivism to myth: Nejedlýs conception of the history of modern Czech music, jež je momentálně v tisku coby součást kolektivní monografie vydané nakladatelstvím Cambridge Scholars Publishing. 
konceptuálního modelu a narativního mechanismu v pozadí první, rídící úrovně. Funkce této úrovně spočívá v „definováni““ obecného Velkého českého skladatele.

Nejedlého výklad těží velkou část své rétorické energie z metaforické adekvace mezi explicitním př́během - sumou biografií velkých českých skladatelů - a skrytým narativním prototypem, převzatým z křest'anské mytologie a věrouky. Dostávaje požadavkům Nietzscheho spisů Zrození tragédie z ducha hudby a $O$ užitku a škodlivosti historie pro život, Nejedlý psal místo historie Mýtus: moderní quasi-mýtus, jenž je „ospravedlněn“ svým systematickým odkazováním k základnímu mytologickému prototypu západní civilisace.

Jak známo, Nejedlého koncepce se zakládá na představě dvou linií vývoje moderní české hudby, rozvíjejících se paralelně od sedmdesátých let 19. století, jedné pokrokové, druhé zpátečnické. ${ }^{14}$ První navazuje na Bedřicha Smetanu a tvoří ji skladatelé Zdeněk Fibich, Josef Bohuslav Foerster a Otakar Ostrčil, př́ípadně ještě Otakar Zich. Druhá následuje Antonína Dvořáka a zahrnuje především jeho žáky Josefa Suka a Vítězslava Nováka, potažmo Leoše Janáčka. Pokroková linie se zaměřovala na rozvíjení programní hudby a post-wagnerovského hudebního dramatu, zatímco druhá linie se soustředila na tvorbu absolutní hudby. Přesto není možné Nejedlého koncepci pokrokovosti a zpátečnictví v hudbě chápat takto jednoduše: jak ukážu později, klíčovým faktorem zakládajícím správnost nebo nesprávnost umění, to jest jeho pokrokovost nebo zpátečnictví, je pro Nejedlého Autor. ${ }^{15}$

Nejedlého koncepce vývoje moderní české hudby je založena na myšlence pokroku, organického rozvíjení pokrokové linie, která je realizací smetanovského, českého ducha. Tato představa pokroku coby realizace ducha představuje ,parafrázi“"křest’anské teleologické představy dějin spásy coby realizace Ducha svatého. Jedná se o radikální koncepci, nebot' připouští jedinou správnou cestu, pevnou a dogmatickou. Tam, kde Nejedlý tu a tam „toleruje“ výjimky, činí tak pouze proto, aby ukázal, že nezdravá vývojová cesta může stvořit velké umění, ale její princip nevyhnutelně vede ke zkáze: ,[...] a dokonaný hřich plodí smrt“ (Jk 1:15). Měli-li bychom v pozadí Nejedlého textů určit nějaký modelový žánr, pak by to patrně byla apologetika. Podle Nejedlého nebyl žádný z velkých českých skladatelů dosud náležitě doceněn a boj za pravou českou národní hudbu zdaleka

14 Tato dichotomie byla patrně do značné míry odrazem dichotomie Wagner-Brahms v dobovém (zejména německojazyčném) diskurzu o hudbě. Je třeba také připomenout, že Nejedlý coby kritik byl jednou z hlavních postav smetanovské strany v „bojích o Dvořáka“, srov. zejm. PEČMAN, Rudolf. Útok na Antonína Dvořáka. Brno: Filozofická fakulta Masarykovy univerzity, 1992. K otázce politické podmíněnosti sporů mezi Smetanovci a Dvořákovci (jakožto obdoby sporů mezi Mladočechy a Staročechy) a k Nejedlého koncepci smetanovské linie moderní české hudby srov. zejm. TYRRELL, John. Czech Opera. Cambridge: Cambridge University Press, 1988, s. 9-12. Samotný Nejedlý byl především ovlivněn svým učitelem Otakarem Hostinským a jeho koncepcí Smetanova významu pro moderní českou hudbu, viz zejm. HOSTINSKÝ, Otakar. Bedřich Smetana a jeho boj o moderni českou hudbu. Praha: J. Laichter, 1901.

15 Obdobné pojetí linií, v nichž na sebe jednotliví skladatelé organicky navazují, i když mnohem složitější, nacházíme v německé hudební historiografii té doby, např. u Waltera Niemanna. 
nebyl vybojován. Všechny zmíněné texty jsou psány z pozice obránce víry, jenž stojí takřka sám proti všem. Nejedlého přimknutí se ke géniovi Smetany a celý následný fanaticky horlivě vedený boj za Smetanu vysvětluje jako obecný kulturní fenomén Nietzsche: „[...] jen ten, kdo své srdce upjal $k$ nějakému velkému člověku, přijal tím první zasvěceni do kultury; jeho známkou je stud bez rozmrzelosti, nenávist vỉči vlastni úzkoprsosti a scvrklosti, soucit s géniem, jenž se vždy znovu vytrhoval z této naši stísněnosti a vyprahlosti, predjímavý cit pro všechny, kdo rostou a zápasí." Po prvním zasvěcení musí podle Nietzscheho následovat druhé, vyšší, znamenající „nejen posuzováni vnějšiho světa, který proudi kolem něho, nýbrž nakonec a především čin, to znamená boj za kulturu a nepř́telství vioči vlivům, zákonům, institucím, v nichž nepoznává svioj cíl: zplození génia.“ ${ }^{16}$ A dále dodává, že „existují lidé, kteři proživají jako své ohrožení, když vidí géniuv svizelný zápas [...], nebo když pozoruji, jak krátkozraké sobectví státu, plytkost podnikavců či suché sebeuspokojení učencủ odsouvá jeho díla lhostejně stranou." 17

V pozadí Nejedlého koncepce a její narativní prezentace jsem odhalil model převzatý z křest’anské mytologie a věrouky: Ježíš coby prorok a mesiáš je prototypem Smetany coby zakladatele moderní české hudby a apoštolové jsou prototypem Smetanových žáků. Obdobu víry představuje moderní česká hudba a její propagace se stává misií. Dvořák a jeho žáci hrají roli falešného proroka respektive falešných apoštolů. Lidstvo je nahrazeno absolutizovaným národem, a Víra a Zákon, které Ježíš přinesl pro spásu lidstva, ${ }^{18}$ jsou nahrazeny velkou národní hudbou, již přináší génius ke spáse svého národa. Děje se tak zcela v duchu náhradní religiozity 19. století, kritizované Kierkegaardem, ${ }^{19}$ jež od svých počátků $\mathrm{v}$ raném romantismu Novalisově a Hölderlinově tíhla k nahrazení víry uměním a apoštola géniem. ${ }^{20}$ Jsem dalek tvrzení, že Nejedlý vytvořil novou filosofii umění coby nového náboženství, podobnou té Wagnerově. Toliko se snažím říct, že v kontextu intelektuálního milieu závěru dlouhého 19. století nebyla myšlenka umění jako náhradního náboženství (at’ už takto explicitně formulovaná, či nikoliv) ničím neobvyklým, ale naopak typickým.

16 NIETZSCHE, Friedrich. Nečasové úvahy. Přel. Jan Krejčí a Pavel Kouba. Praha: OIKOYMENH, 2005, s. 162.

17 Ibid., s. 204.

18 Viz BERKHOF, Louis. Dějiny dogmatu. Praha: Návrat domů, 2003, s. 43.

19 Kierkegaard v eseji Rozdíl mezi géniem a apoštolem (1849) kritizuje dobově příznačný jev, zatahování náboženské terminologie do oblasti estetického diskurzu; zejména kritizuje ztotožňování génia s apoštolem. KIERKEGAARD, Søren. Rozdíl mezi géniem a apoštolem. In Søren Kierkegaard. Má literární činnost. Přel. Marie Mikulová Thulstrupová. Brno: Centrum pro studium demokracie a kultury, 2003, s. 49.

20 Srov. BROWN, Julie. Understanding Schoenberg as Christ. In The Oxford Handbook of the New Cultural History of Music. Jane F. Fulcher (ed.). Oxford: Oxford University Press, 2011, s. 117-162. Brownová v této studii podává analýzu intelektuálního kontextu (Wagner, George, Weininger) Vídně období fin de siècle, v němž se zrodil quasi-religiózní kultický diskurz Schönbergových žáků, pojímajících jej jako nového Krista. 
Onen narativní model v pozadí koresponduje se strukturním modelem, z nějž je odvozen Nejedlého konstrukt Velkého českého skladatele. Tímto strukturním modelem je křest’anský světec a mučedník. ${ }^{21}$ Př́iběh Smetany a jeho žáků, kteř́ trpěli stejně jako jejich mistr a neochvějně zvěstovali evangelium nového umění, pro něž je jejich vlastní národ utýral, parafrázuje novozákonní př́iběh Ježíše, apoštolů a jejich dalších pokračovatelů, křest’anských světců. Světec je mučedník, který mnoho trpěl a obětoval svůj život pro víru, čímž dosáhl svatosti; slovy Ježíše: „Každý, kdo se ke mně prizná před lidmi, $k$ tomu se i já přiznám pred svým Otcem v nebi.“ (Mt 10:32). ${ }^{22}$ Apoštolové jsou v křest’anské věrouce obecně pojímáni jako světci, kteří byli vyvoleni, aby uzřeli velikost Ježíše, na základě toho šírili Ježíšovo učení a kázali radostnou zvěst, že vstal z mrtvých a že je Pán (Sk 10:40-42); byli povoláni stát se „světlem národů/pohanư“, aby Kristova spása došla „až na sám konec země“ (Sk 13:47).23

Tak jako mučednický život světců zakládá a do značné míry podmiňuje jejich svatost, tak také mučednický život umělců zakládá a podmiňuje jejich velikost. ${ }^{24}$ Podle Nejedlého výkladu všichni velcí čeští skladatelé mnoho trpěli a byli svým vlastním národem utýráni $\mathrm{k}$ smrti poté, co mu přinesli spásu v podobě velkého národního umění; ve svém utrpení však byli neústupní, vytrvalí a horliví, tak jako byli Ježíš a křest’anští mučedníci neústupní (1 K 15:58), vytrvalí (Mk 13: 5-13; Žd 10:36) a horliví (J 2:13-17) ve svém utrpení pro víru. Vysvětlení smyslu utrpení apoštolů a raných křest’anů, respektive mučednictví jakožto principu jejich života, podává obsáhlá pasáž z Matoušova evangelia (10:16-39): apoštolové jsou zde prrirovnáváni k ovcím mezi vlky a mučení ze strany nepřátel je podáváno jako zkouška jejich věrnosti a síly jejich víry: „Budou vás všichni nenávidět pro mé

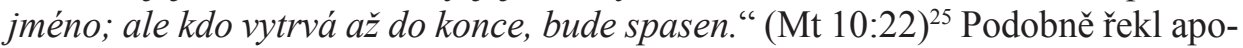
štol Pavel: „Vím [...], že mi Duch svatý město od města ohlašuje, že na mne čekají pouta a utrpení. Ale já nepřikládám svému životu žádnou jinou cenu, než abych dokončil svi̊j běh a splnil úkol, který jsem dostal od Pána Ježíše“. (Sk 20:23-24) Naproti tomu se skladatelé náležející do zpátečnické linie, Nejedlým implicitně líčení jako falešní apoštolové, už za svého života dočkali velkého uměleckého i finančního úspěchu.

21 Tomu odpovídající romantický, v zásadě beethovenovský mýtus umělce coby „trpícího hrdi$n y^{\prime \prime}$ [suffering hero] se v průběhu 19. století široce rozšíril takřka po celé Evropě, viz KERMAN, Joseph. How We Got into Analysis, and How to Get out. Critical Inquiry, 1980, roč. 7, č. 2, s. 314.

,[...] abyste sami sebe prinášeli jako živou, svatou, Bohu milou obět; to at' je vaše pravá

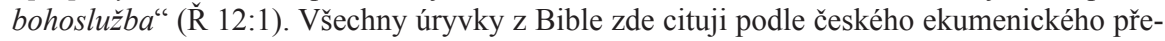
kladu, především podle jeho vydání z roku 1985. Viz též Mk 3:14-15.

24 K vizi mučednictví, „,snu o trnové koruně“ v českém národním vědomí 19. století, zejména k př́ípadu Karla Havlíčka Borovského, srov. MACURA, Vladimír. Český sen. Praha: Nakladatelství Lidové noviny, s. 119-128.

25 Smysl utrpení je rovněž diskutován ve Sk 14:22. K teologickému výkladu smyslu Kristova utrpení srov. BERKHOF, op. cit., s. 27. 
Odhalení exploatace biblického modelu v pozadí Nejedlého koncepce se jeví překvapivým nebo až neuvěřitelným vzhledem $\mathrm{k}$ tomu, že Nejedlý bývá v rámci českých kulturních a politických dějin nejčastěji ztotožňován se svým opakovaným působením ve funkci ministra v komunistických vládách po roce 1946 a se svou radikálně levicovou politickou orientací po roce 1920. Dané odhalení přestává být až tak překvapivým, uvědomíme-li si tři věci. Zaprvé, Nejedlého intelektuální východisko před rokem 1920 rozhodně nemůžeme nazvat marxistickým. Naopak, představovalo konglomerát nejrůznějších myšlenkových tradic, tendencí, vzorců a postupů 19. století, počínajíc živelně pojatou hegelovskou dialektikou a fenomenologií ducha a končíc psychiatrickou kasuistikou osobnosti, spojujíc v sobě romantický kult génia a intuitivismus s pozitivistickým scientismem, a mnohým jiným. Zadruhé, model převzatý z biblické mytologie je snad tím nejpevněji zakořeněným narativním prototypem západní kultury, proto snad žádný jiný nemůže v pozadí západního ideologického diskurzu působit účinněji. A zejména, zatřetí, jak opakovaně zdůrazňuje Hayden White, implicitní ideologie narativního modelu a explicitní ideologie diskurzu spolu nemusejí v zásadě nijak korespondovat. Korespondence probíhá pouze na formální úrovni: vychází $\mathrm{z}$ adekvace mezi formou modelu a formou výsledného tvaru. A právě tato formální korespondence uvolňuje stavidla emocionální a auratické energie v pozadí zdánlivě „vědeckého“ diskurzu.

Není zde prostor podrobně sledovat, jak zjevná rovina Nejedlého narativu odkazuje na rovinu latentní. Zaměřím se však podrobněji na klíčový dílčí koncept Nejedlého koncepce, totiž na zmíněný konstrukt Velkého českého skladatele. ${ }^{26}$ V Nejedlého chápání jsou vlastnosti moderního uměleckého díla př́mým odrazem vlastností jeho tvůrce, autora: abychom pochopili dílo moderního skladatele, musíme především poznat psychologický a životopisný profil jeho osobnosti; proto je také velikost moderního uměleckého díla podmíněna lidskou velikostí jeho tvůrce. Autor zde plní funkci oné foucaultovské instituce, jež funduje velikost a smysl díla, dává mu hodnověrnost a posvěcuje je. ${ }^{27} \mathrm{~V}$ tomto ohledu byl Nejedlý zjevně také ovlivněn diltheyovskými duchovědami. ${ }^{28}$

Četnost velkých skladatelů se podle Nejedlého v 19. století výrazně snížila, nebot' od Beethovenových dob se po umělci žádá, aby byl především velkým člověkem: conditio sine qua non ,umělecké velikosti“ je „velikost člověka“; velký moderní umělec musí mít bezpodmínečně „vynikajicí lidský karakter ${ }^{\text {“ }} .{ }^{29} \mathrm{~V} \mathrm{Ne}-$ jedlého výkladu jsou kladné povahové vlastnosti velkých českých skladatelů tak

26 Jenom pro pořádek zdůrazňuji, že Nejedlý takto daný prvek své koncepce nenazýval: jedná se o výsledek a operativní pojem mé vlastní analýzy.

27 FOUCAULT, Michel. Řád diskurzu. In Michel Foucault. Diskurs, autor, genealogie: 3 studie. Praha: Svoboda, 1994, s. 16 ff.

28 Zejména Diltheyovým spisem Das Erlebnis und die Dichtung (1906), viz STŘíTECKÝ HANZAL, op. cit., s. 25.

NEJEDLÝ, Smetaniana I., op. cit., s. 116. 
zbytnělé a záporné vlastnosti tak zakrnělé, že se tito jeví jako ideální lidé, nadlidé, světci.

Ačkoliv se jednotliví velcí čeští skladatelé v mnoha ohledech liší, jejich základní povahové rysy, jakési strukturní konstanty jejich osobností, zůstávají stejné. Nejedlý nikde explicitně nevysvětluje, kdo je podle něj obecně velkým českým skladatelem; přesto je modelový Velký český skladatel implicitně obsažen v souhrnu Nejedlého textů. Jednotliví velcí čeští skladatelé mají v mimořádné míře vyvinuté některé společné povahové vlastnosti, jež navzdory výrazným rozdílnostem v povahách jednotlivých mistrů fungují jako stmelující faktor jejich skupiny a zároveň je odlišují od ostatních, v Nejedlého chápání menších skladatelů. A tato domnělá struktura osobnosti, vyjevující se $\mathrm{v}$ jejich povahových vlastnostech a $v$ jejich osudu, je tím jediným, co v Nejedlého koncepci sjednocuje všechny velké české skladatele a vede čtenáře $\mathrm{k}$ vytváření si obrazu noumenálního Velkého českého skladatele, jehož jsou tito jednotlivci pouze fenomenálními realizacemi. Konceptuální předobraz takovéto skupiny pokrokových skladatelů obdařených smetanovským duchem můžeme najít v Augustinově koncepci Církve coby communionis sanctorum, skupiny vyvolených, kteř́ byli nadáni Duchem svatým. ${ }^{30}$ Podobně ale také Kant napsal o géniovi: „Ideje umělce vzbuzuji podobné ideje u jeho učně, jestliže ho príroda obdařila podobnou proporcí duševnich sil.“" ${ }^{31}$ Totožnost povahových vlastností, osudu a chování Ježíše a apoštolů vyplývá z mnoha míst Nového zákona: např́klad apoštol Petr se poté, co na něj sestoupí Duch svatý, začne chovat jako Ježíš, apoštolové konají zázraky, jako konával Ježíš, apod. ${ }^{32}$ Nacházíme ji také v Pavlově výzvě bratrům: „Jednejte podle mého přikladu, jako já jednám podle př́kladu Kristova." (1 K 11:1) ${ }^{33}$ A ve Skutcích (4:32) se píše: „Všichni, kdo uvěřili, byli jedné mysli a jednoho srdce“. I přes všemožné rozdíly spojuje velké české skladatele především základní smetanovský povahový rys: kladnost pohledu na svět. Některé z dalších dílčích vlastností odpovídají romantické představě génia, některé se od ní výrazně odklánějí, přičemž Smetana coby reprezentant mesiáše disponuje těmito vlastnostmi v absolutní míře, takže se jeví jako nadčlověk. Nejedlý otevírá celou kapitolu o Smetanovi ve svých Dějinách české hudby v tomto ohledu příznačným konstatováním, že Smetana „byl z nejryzejšich lidí všech dob a národ ¿ّ“. ${ }^{34}$

Na základě souhrnné komparativní analýzy Nejedlého textů pojednávajících velké české skladatele můžeme vyčlenit a systematizovat obecné typologické atributy postavy Velkého českého skladatele podobně, jako činí Propp s postavami ruských

30 Je velmi pravděpodobné, že Nejedlý byl obeznámen s Augustinovým dílem; srov. Zdeněk Nejedlý. Politik a vědec v osamění. Praha - Litomyšl: Paseka, 2012, s. 28-42.

31 KANT, Immanuel. Kritika soudnosti. Přel. V. Špalek a W. Hansel. Praha: Odeon, 1975, s. 127.

32 Viz např. Sk 3:6-8.

33 Respektive v Ga 4:12.

34 NEJEDLÝ, Dějiny české hudby, op. cit., s. 173. 
čarodějných pohádek. ${ }^{35}$ Takováto analýza odhalila jedenáct hlavních vlastností Velkého českého skladatele: prostotu, mužnost, jemnost, pokrokovost, životnost, mravní velikost, čistotu, duchovnost, uměleckou vážnost, lidovost a duševní aristokratismus.

1) Prostota. Pro Velkého českého skladatele je charakteristická sympatická naivita myšlení a cítění, nebo dokonce nepraktičnost; je nesobecký, skromný a mírný, v běžném životě konservativní; naprosto postrádá rafinovanost, je spíše asketické než požitkářské povahy; vůbec jej nezajímá finanční úspěch, luxus a sláva: proto se nikdy nesníží $\mathrm{k}$ tvorbě lehkého umění a nikdy nepodléhá módním vlivům. 2) Mužnost. Má pevný, sebevědomý charakter. 3) Jemnost není neslučitelná s mužností: $\mathrm{v}$ běžném životě je něžný, citlivý, mírný, soucitný a nebojovný. 4) Pokrokovost. Ve své hudbě vytváří zcela nové světy a směřuje k novým cílům; ${ }^{36}$ jeho myšlení je originální, má absolutně pokrokového ducha a je ideově uvědomělý; je svého druhu novým člověkem, novou osobností. 5) Životnost. Má veselou, radostnou, hřejivou a přátelskou povahu, velký smysl pro humor, mladistvé srdce a mladistvého ducha, jakož i pozitivní pohled na svět; miluje svět, život a prírodu. 6) Mravní velikost. Má silně vyvinuté svědomí, smysl pro pravdu a spravedlnost. 7) Čistotou je míněna upř́mnost, zejména uprímnost citu (potažmo i náboženské víry ve Foersterově případě), přirozenost a naivnost. 8) Duchovnost. Velký český skladatel je spíše spirituální než senzuální povahy; nemá zálibu ve vnější kráse, ale oceňuje zejména krásu vnitřní; světské záležitosti jsou pro něj malicherné, nebot' svůj zrak stále obrací výše; jeho bytostným, zvnitřněným světonázorem je absolutní idealismus. 9) Vážnost tvorby. Pravý umělec přesně ví, co a jak tvoří, tvoří tedy s jistotou; je mu vlastní zralost a vnitřní koherence, jež podmiňuje koherenci jeho díla; pracuje soustavně a př́ísně, velikostí jeho úkolu roste velikost jeho práce; je disciplinovaný, skromný, ale vědomý si své velikosti a ceny; v uměleckých věcech je naprosto neústupný, bojovný a zásadový. 10) Lidovost. Žije v nejužším styku se současným životem; je venkovským typem člověka, zdravý, solidní, nezkažený městským životem, v jeho povaze převažují dobrota srdce, lidumilnost, lidskost a soucit. 11) Duševní aristokratismus není v rozporu s předchozí vlastností, lidovostí; tímto pojmem Nejedlý explicitně označuje noblesu, kultivovanost, mimořádnou vzdělanost, komplikovanost a bohatost umělcova ducha.

35 Viz např. PROPP, Vladimír. Transformace čarodějných pohádek. In Poetika rytmus verš. Jurij Lotman (ed.). Praha: Svět sovětů, 1968, s. 84. Pro rozsáhlejší strukturní analýzy viz zejm. PROPP, Vladimir Jakovlevič. Morfologie pohádky. In Týž. Morfologie pohádky a jiné studie. Jinočany: H \& H, 2008, s. 11-124.

36 K původu představy, že velký skladatel otvírá nové světy, u E. T. A. Hoffmanna viz MAUS, Fred Everett. Concepts of Musical Unity. In Rethinking Music. Nicholas Cook - Mark Everist (eds.). Oxford: Oxford University Press, s. 187. 
Nyní ukážu a vysvětlím prototypy těchto povahových vlastností ve vlastnostech ideálního křest’ana; ${ }^{37}$ odkazovat budu především k textům Nového zákona, což odpovídá Nejedlého obdivu k ,prvnímu křest'anstvi“. Zároveň upozorním na podobné momenty v dominantních koncepcích génia zrozených v 19 . století (Kant, Schopenhauer, Nietzsche), s nimiž byl Nejedlý patrně rovněž dobře obeznámen. ${ }^{38}$

Ad 1) Prostota - v různých podobách - je typickou vlastností křest’anských světců (Sk 4:13). ${ }^{39}$ Jak stojí v Prvním listu Timoteovi (1:5): „Cílem našeho vyučování je láska $z$ čistého srdce, $z$ dobrého svédomí a $z$ upř́mné víry. "V Žalmech (24:4-5) se zase praví: „Ten, kdo čisté ruce má a srdce ryzí, ten, kdo duši nepozvedá k nepravosti, ten, kdo nepřisahal lstivě. Ten od Hospodina dojde požehnáni" A předobraz požadavku ignorování současnosti nacházíme v listech Římanům (12:2): ,„...] neprizpưsobujte se tomuto věku“. Podle Schopenhauera mívají géniové dětinskou povahu, s čímž souvisí jejich typická naivita a „vznešená prostota a také podle Nietzscheho je prostota jednou ze základních charakteristik génia.

Ad 2) Mužnost je obdobou odvážnosti, neohroženost a síly víry. Jako taková Ježíše stejně jako apoštoly a jiné křest’anské světce (Ef 6:10-18; Sk 4:13, 29, 31). Jak se praví v Žalmech (27:14): „Vzchop se a bud’ statečného srdce, naději slož $v$ Hospodina!" Podle Nietzscheho se génius vyznačuje vnitřní silou a odvahou: je v zásadě bojovníkem: „,[...] nejpodmanivějši př̉iklad, jaký pred sebou vidíme, přiklad Richarda Wagnera, nám ukazuje, že se génius nesmí bát ani sebenevraživějš́ roztržky s existujicimi formami a pořádky, chce-li ze sebe vynést na světlo vyšši řád a živou pravdu“. ${ }^{40}$

Ad 3) Jemnost, pokora a nebojovnost $\mathrm{v}$ běžném životě má předobraz např. v požadavku z Matoušova evangelia (5:39): ,[...] kdo tě uhodi do pravé tváre, nastav mu i druhou“. Nebo v Listu Efezským (4:31-32): „At’ je vám vzdálena všechna tvrdost, zloba, hněv, křik, utrhání a s tím i každá špatnost; bud'te k sobě navzájem laskaví, milosrdní, odpouštějte si navzájem“. Či v Listu Koloským (3:12-13): „[...] oblečte milosrdný soucit, dobrotu, skromnost, pokoru a trpělivost. Snášejte

37 K mytologické koncepci Ježíše jakožto ideálního člověka a vzoru dokonalosti viz zejm. CAMPBELL, Joseph. The Masks of God: Occidental Mythology. New York: Penguin Books, 1991, s. 334-361.

K obecným dějinám koncepcí génia v 19. století viz zejm. Genius: The History of an Idea. Penelope Murray (ed.). London: Blackwell, 1989. Dnes již klasickým muzikologickým dílem zabývajícím se sociálním konstruktem génia je DeNORA, Tia. Beethoven and the Construction of Genius: Musical Politics in Vienna, 1792-1803. Berkeley and Los Angeles: University of California Press, 1995.

Teolog Josef Zvěřina napsal: „Prostota křest'anu vrývá zvláštní šlechtictví ducha.“ Odvaha být církví. Josef Zvěřina v letech 1913-1967. Vojtěch Novotný (ed.). Praha: Karolinum, 2013, s. 444. 
se navzájem a odpouštějte si, má-li kdo něco proti druhému. "Podle Schopenhauera je génius vnitřně silný a mužný, ale zároveň přecitlivělý;" jak vidno, nacházíme $v$ jeho koncepci génia ambivalenci mužnosti a jemnosti podobně jako v koncepci nejedlovské.

Ad 4) Pokrokovost znamená službu pokroku, jenž je obdobou křest’anské teleologické představy dějin spásy. Novost Evangelia širreného apoštoly je konceptuálním prototypem novosti pokrokového umění šířeného pokrokově smýšlejícími umělci. Nejedlý přikládá hudbě v rámci kulturní emancipace českého národa zásadní roli, proto se Umění se v jeho koncepci stává Hudbou. Ve Skutcích apoštolů je Ježíšovo učení představováno jako pokrokové ve srovnání s tradicí Starého zákona, a to nejen v rovině duchovní, ale i praktické (kritika farizejů atd.). Ježíš přišel nikoliv proto, aby „zrušil Zákon“, ale aby jej „naplnil“ (Mt 5:17). Obdobně tomu Smetana nepřišel zrušit „starý zákon“ českého obrození - které Nejedlý v návaznosti na Palackého, Masaryka a Jiráska chápe jako vyvrcholení všech předchozích pokrokových tendencí českého národa - ale naplnit jej. Podle Kanta génius nenaplňuje pravidla umělecké tvorby, nýbrž je sám vytvárí́; originalita je proto, spolu se svobodností, základní vlastností génia. ${ }^{42}$ Obdobně tomu píše Nietzsche: „Po neznámé cestě, přerušované tisícem propastí, nikdo nechodí strnulým krokem: ale génius po takové stezce běži hbitě, [...] vysmivaje se [...] bázlivému odměrování krokư“. ${ }^{43}$

Ad 5) Požadavek životnosti jako radostnosti rovněž nacházíme na mnoha místech Nového zákona (L 10:20; J 15:11). Ježíš řekl svým učedníkům: „Z toho se radujte, $i$ když snad máte ještě nakrátko projít zármutkem rozmanitých zkoušek.“(1 Pt 1:6) A apoštolové byli naplněni „radostnou myslí, že se jim dostalo té cti, aby nesli potupu pro jeho jméno" (Sk 5:41). Podle Schopenhauera je géniova povaha melancholická, ovšem ve smyslu radosti ve smutku a smutku v radosti; běžní lidé jsou usedle vážné (protože ovládané) loutky, génius je veselý (protože svobodný) loutkoherec. ${ }^{44}$

Ad 6) Morální velikost, zejména smysl pro pravdu (J 14:6, 17:17) a spravedlnost (Mt 5:6, 6:33) je projevem pravé křest'anské víry; pravda a spravedlnost jsou křest’anovými hlavními zbraněmi: ,[...] přemýšlejte o všem, co je pravdivé, čestné, spravedlivé, čisté, cokoli je hodné lásky, co má dobrou pověst, co se považuje za ctnost a co sklízi pochvalu." (Fp 4:8)

41 SCHOPENHAUER, Arthur. Svět jako vůle a představa. Svazek II. Přel. M. Váňa. Pelhřimov: NTP, 1998, s. 284-285.

42 KANT, op. cit., s. 125-127.

43 NIETZSCHE, op. cit., s. 55.

44 „Tak většinou melancholický génius ukazuje [...] specifickou jarost, jež je možná jen u něj a vyvěrá z nejdokonalejši objektivity ducha“. SCHOPENHAUER, op. cit., s. 281. 
Ad 7) Také čistota představuje jednu z klíčových vlastností pravého křest’ana (Mt 5:27-32; 1 Tm 4:12); pravý křest’an má prosté a čisté srdce (2 Tm 2:22). V Druhém listu Korintským (7:1) stojí tato výzva: „,...] očist'me se od každé poskvrny těla i ducha". Podle Nietzscheho je génius čistý člověk, jenž pohližź na věci ,čistě a s láskou“. ${ }^{45}$

Ad 8) Duchovnost má rovněž předobraz v Novém zákoně: „Kdo přicházi shưry, je nade všecky. Kdo pochází ze země, náleži zemi a mluví o pozemských věcech.“ (J 3:31) Nebo vzpomeňme, co křičel rozlícený Petr na Šimona: „Tvé penize at’ jsou zatraceny i s tebou: Myslil sis, že se Boži dar dá získat za penize" (Sk 8:20); nebo co se praví o kousek dál: „Od nikoho jsem nežádal stříbro, zlato ani oděv.“ (Sk 20:33) Podle Schopenhauera se génius vyznačuje abnormální převahou nejušlechtilejší ze tří fyziologických sil, „senzibility“ (vzdělávání, myšlení, objevování, čtení, filosofování), nad ostatními dvěma, ,iritabilitou“ (lov, válčení) a „reprodukční silou“ (jídlo, pití, spánek, odpočinek). Géniové se na rozdíl od běžných lidí „často špatně staraji o své vlastní blaho“, nebot’ se obětují vyššímu účelu. Nemohou jinak, a proto jsou velcí. Malý člověk veškeré své snažení směřuje k sobě, velký člověk - proto, že se poznává ve všem, v celku, své snažení směřuje mimo sebe, pro všechny, a přispívá tak k ,osviceni“" světa. ${ }^{46}$

Ad 9) Absolutní vážnost tvorby a oddanost velkému pokrokovému umění má předobraz v „,největším a prvním prikiázáni"“ Nového zákona: „Miluj Hospodina, boha svého, celým svým srdcem, celou svou duši a celou svou mysli“" (Mt 22:37). Je analogií pevnosti víry, předepsané např. v Matoušově evangeliu (8:5-13) nebo v Markově evangeliu (11:22-24), a věrnosti, předepsané v Matoušovi (25:23) nebo v Prvním listu Korintským (4:2). A v Janově evangeliu (9:4) stojí: „,Musíme konat skutky toho, který mě poslal“. Pravá víra je nekompromisní a bojovná - jak řekl Ježíš: „,[...] nepriš̌el jsem uvést pokoj, ale meč" (Mt 10:34). Podle Nietzscheho myslí génius vážněji než obyčejní lidé, nebot' zahlédl něco vyššího, „strašlivou nadpozemskou scénu soudu, při němž byl vážen všechen život, i nejvyšši a dokonalý, a byl shledán přiliš lehkým". Je tudíž zřejmě, že potom vše měří sub specie aeternitatis a nemá „,chut' zabývat se takzvaným ,uměním ' po učeném a licoměrném způsobu modernich lidi"“. ${ }^{47}$

Ad 10) Povahové vlastnosti sjednocené v Nejedlého konceptu lidovosti opět odpovídají charakteristikám ideálního křest’ana, konkrétně požadavku dobročinnosti, křest’anské lásky a skromnosti (L 18:9-14; Fp 2:3-11). Jak stojí v Prvním listu Petrově (2:17): „Ke všem lidem mějte úctu, bratrstvo milujte“.

\footnotetext{
45 NIETZSCHE, op. cit., s. 214.

46 SCHOPENHAUER, op. cit., s. 281-285.

47 NIETZSCHE, op. cit., s. 209.
} 
Ad 11) Duševní aristokratismus má svůj předobraz v novozákonním požadavku dokonalosti křest'anských světců respektive svatosti křest'ana: „Bud'te tedy dokonalí, jako je dokonalý váš nebeský otec.“ (Mt 5:48) „[...] jako je svatý ten, který vás povolal, bud'te $i$ vy svatí v celém zpuisobu života“. (1 Pt 1:15). Není snad ani třeba připomínat, že Nietzscheho koncepce génia má $\mathrm{v}$ zásadě aristokratický charakter; a také schopenhauerovský génius je člověk schopný zř́í ,velké prav$d y^{\prime \prime}$ a tvořící nesmrtelná díla, v nichž je reprodukuje. Tím, co podle Schopenhauera odlišuje génia od sebemoudřejších avšak negeniálních lidí, je nepraktické zaměření jeho intelektu, jenž je odloučený od vůle, svobodný; proto má génius sklon $\mathrm{k}$ výstřednostem, ba pošetilostem, je vystaven strádání a v mnoha ohledech př́ibuzný š́lenci. ${ }^{48}$

Jak vidíme, v dílčích rysech mají hlavní koncepce génia podivuhodně blízko $\mathrm{k}$ obrazům světců. Bylo by tedy těžké, ne-li nemožné, snažit se v tomto př́ípadě o přesné vysvětlení Nejedlého inspiračních zdrojů, protože můžeme předpokládat, že se všemi zmíněnými potenciálními inspiračními zdroji byl v době, kdy svou koncepci vytvářel, obeznámen.

Povahové vlastnosti Nejedlého Velkého českého skladatele a jejich prototypy lze rovněž subsumovat pod čtyři tzv. kardinální křest’anské ctnosti, vymezené Tomášem Akvinským v Sumě teologické II (I).47-110, knize, kterou Nejedlý patrně také znal. Těmito ctnostmi a jejich analogony v Nejedlého koncepci jsou:

(1) „,moudrost“ (prudentia) - vážnost tvorby, duchovnost, duševní aristokratismus, životnost, pokrokovost;

(2) „spravedlnost“" (iustitia) - morální velikost;

(3) „statečnost“ (fortitudo) - mužnost;

(4) „umírněnost“ (temperantia) - prostota, lidovost, čistota, jemnost.

Modelové vlastnosti Velkého českého skladatele tedy mají své mytologické předobrazy ve vlastnostech ideálního křest’anského světce. Navzájem se konceptuálně provazují, jedna je často variantou jiné, nebo jedna „vysvětluje“ jinou, a dohromady vytvářejí koherentní obraz dokonalého člověka, světce, ideálního typu, jenž je ideální, protože vyvážený, v němž se mužnost nevylučuje s jemností a duševní aristokratismus s lidovostí, protože se navzájem doplňují. Dodejme, že Nejedlého představa Smetany jakožto v prvé řadě dokonalého člověka má patrně své prvotní kořeny ve smetanovských esejích Charlotty Garriguové, publikovaných v časopisu Naše doba v roce $1894 .{ }^{49}$

Naopak u těch skladatelů, kteří podle Nejedlého představují zpátečnickou linii vývoje české moderní hudby (Dvořák, Suk, Novák), některá ze zmíněných povahových vlastností úplně chybí nebo není s ostatními v rovnováze, pročež zbytňuje: to je př́íad Dvořáka, jehož lidovost není vyvážena duševním aristokratismem

48 SCHOPENHAUER, op. cit., s. 284-285.

49 Garriguové představa lidské dokonalosti nese výrazné stopy protestantské etiky; v Nejedlého koncepci je tento aspekt utlumen. Viz MASARYKOVÁ-GARRIGUE, Charlotte. O Bedřichu Smetanovi. Praha: Sbor pro postavení pomníku B. S., 1930. 
a ideovou uvědomělostí. ${ }^{50}$ Také Janáčkovi a Sukovi chybí duševní aristokratismus, a ani u Nováka, jehož si Nejedlý ze všech dvořákovských skladatelů cenil nejvíc, není přítomen $\mathrm{v}$ dostatečně velké míře, Novák navíc postrádá niternou českost a lidovost, a v podobných kombinacích bychom mohli pokračovat... Především jsou však všem nepokrokovým skladatelům vlastní dvě základní negativní vlastnosti: nepoctivost či neupř́mnost a nepokrokovost. ${ }^{51}$

Nejedlého Velký český skladatel dialekticky osciluje mezi lukácsovským ,průměrným hrdinou" [mediocre hero] a jeho protikladem: na jedné straně - v běžném životě - je ,průměrným" [mediocre], „nejistým" [wavering] a „pasivním“ [passive] ${ }^{52}$ človíčkem, zatímco na druhé straně - ve světě umění - se chová jako výjimečný, sebejistý a bojovný génius. Tuto dvojakost Nejedlý konceptualizuje na základě dichotomie soukromého, každodenního, pozemského bývání (coby existence) na straně jedné, a uměleckého, metafyzického bytí (coby konání) na straně druhé. Tím patrně vnitřně nejrozporuplnějším rysem Nejedlého koncepce je však kombinace proklamované lidovosti a demokratičnosti na straně jedné a pohrdlivě elitářský až výsměšný tón na straně druhé. Ono elitářství Nejedlý nepochybně převzal z diskurzů o géniovi, jež byly v 19. století ostře elitářské, stavíce na dichotomii génius vs. obyčejný člověk, přičemž prvý býval pojednáván jako svého druhu nadčlověk (eventuálně pravý člověk) a druhý jako hmyzí duše přebývající v lidském těle.

Velcí čeští skladatelé v Nejedlého koncepci jsou podle Kierkegaardovy dichotomie mnohem spíše apoštoly než génii, nebot' génius má být hodnocen „,̌istě esteticky podle svého obsahu, své specifické hodnoty“, kdežto „apoštol je tím, čim je faktem božského zmocněni" ${ }^{53}$ Génius žije sám pro sebe, jeho činnost má smysl především pro něj a z něj (imanentní teleologie), apoštol žije pro všechny kromě sebe, jeho činnost má smysl absolutní a je naplňováním vyšší moci (absolutní teleologie). Apoštol je muž vyslaný Bohem v pověření zvěstovat Učení. A toto Učení, které jej kvalitativně funduje, nemá být hodnoceno esteticky nebo filosoficky, ani z hlediska duchaplnosti. Tím, co zhodnocuje Učení, je samotná skutečnost ,zjeveni““. Před apoštolem se neskláníme proto, že je duchaplný, ale proto, že má ,zmocněni". Apoštol za Učení dobrovolně obětuje život a vše: tím své učení kvalifikuje jakožto Učení. Tak je tomu i v Nejedlého koncepci: sebekrásnější (ve formálním smyslu) a sebe duchaplnější (v pozemském slova smyslu) hudba nezakládá opravdovou velikost svého tvůrce, není-li kvalifikován povoláním zvěstovat Učení: to je př́ípad Dvořáka a Kovařovice.

50 Beckerman napsal: „It is Nejedly, as much as anyone else, who is responsible for a defensive hagiography at the core of Dvoŕák studies. "BECKERMAN, Michael B. New Worlds of Dvorák: Searching in America for the Composer's Inner Life. New York, London: W. W. Norton \& Company, 2003, s. 8.

51 K diskusi nepoctivosti v Novém zákoně viz zejm. Sk 8:18-21.

52 LUKÁCS, György. The Historical Novel. London: Merlin, 1962, s. 30 ff.

53 KIERKEGAARD, op. cit., s. 51. 
Jeden z kořenů konceptu skladatele-apoštola nacházíme ve Wagnerově předsmrtném krédu: „Ich glaube an Gott, Mozart und Beethoven, ingleichem an ihre Jünger und Apostel." "54 Wagnerova vize umělce budoucnosti je vizí umělce coby apoštola, jenž je pouze zprostředkovatelem vůle národa, lidu..$^{55}$ Obdobně tomu je pro Nejedlého smetanovská hudba realizací imanentní českosti svých tvůrců coby českosti vůbec.

Dar specifického Ducha (českého, smetanovského), bez nějž je všechno umělecké snažení předem marné, je konceptuální obdobou daru Ducha svatého, znamenajícího schopnost být v Bohu a s Bohem: „Já jsem vinný kmen, vy jste ratolesti. Kdo zůstává ve mně a já v něm, ten nese hojné ovoce; nebot' beze mne nemůžete činit nic." (J 15:5). Tento dar zakládá a umožňuje apoštolství, tak jako u Nejedlého smetanovský duch přítomný ve velkých českých skladatelích zakládá a umožňuje tuto jejich velikost coby návaznost na Smetanu. Apoštolství coby bytí obdarován Duchem svatým je opakovaně zmiňováno ve Skutcích: okamžik naplnění Duchem svatým byl pro apoštoly rozhodující, protože zakládal jejich skutečné apoštolství coby schopnost založit Církev (Sk 2), dával jim „silu“ a schopnost být ,svědky “ Ježíšovými (Sk 1:8). ${ }^{56}$ Naplněnost Duchem svatým je podmínkou uzření absolutna (Sk 7:55-56); v př́ípadě apoštolů je důkazem Pánovy milosti, umožňujícím konat znamení a zázraky (Sk 14:3, 19:11). V prŕípadě velkých českých skladatelů naplněnost smetanovským (českým) Duchem podmiňuje schopnost vytvářet velké (české) umění.

Tolik ke společným povahovým vlastnostem a společnému duchu velkých českých skladatelů; co však onen jejich společný osud? Podle Whitea je pro odhalení narativního prototypu $\mathrm{v}$ pozadí zjevné roviny historiografického diskurzu klíčové určit, které prvky a momenty této zjevné roviny jsou zdůrazněny. V Nejedlého diskurzu jsou opakovaně zdůrazňovány ty momenty, které spojují velké české skladatele s implicitním obrazem trpících světců: žádný z těchto skladatelů se během svého života nedočkal uznání, jelikož tvořili umění budoucnosti, a jejich vlastní národ je utýral $\mathrm{k}$ smrti poté, co mu přinesli spásu v podobě velkého národního umění.

Především musíme říct, že Nejedlého koncepce Smetany coby nesporného a jediného zakladatele moderní české hudby, jenž byl však odmitnut svým lidem, odpovídá líčení Jěžíše ve Skutcích (4:11-12): „Ježíš je ten kámen, který jste vy stavitelé odmitli, ale on se stal kamenem uhelným. V nikom jiném neni spásy; neni pod nebem jiného jména, zjeveného lidem, jímž bychom mohli být spaseni. “57 Následujíce Ježíšova príkladu, apoštolové byli nejen mučeni či umučeni, ale také

54 WAGNER, Richard. Ein deutscher Musiker in Paris. Novellen und Aufsätze. Leipzig: Insel-Verlag, 1914, s. 62.

55 „Das Kunstwerk ist die lebendig dargestellte Religion; - Religionen aber erfindet nicht der Künstler, die entstehen nur aus dem Volke." WAGNER, Richard. Das Kunstwerk der Zukunft. Leipzig: Otto Wigand, 1850, s. 36.

56 Srov. též Sk 4:31, 5:32, 15:8-10.

57 Srov. rovněž Pavlovu připomínku Izaiášova proroctví (Sk 28:25-26). 
uráženi, vysmíváni a považováni za šarlatány, falešné apoštoly a kacíře (Sk 6:1113) nebo blázny (Sk 2:13, 26:24); bylo jim zakazováno a zamezováno šírit učení jejich mistra (Sk 4:18). Obdobně tomu považovali Češi velké české skladatele, zejména Smetanu a Fibicha, za „německé" skladatele, Fibicha dokonce za „,anti-smetanovce“, atp. To vše se v obou př́padech dělo především kvůli závisti (Sk 5:17-18). Samotné mučednictví bylo dlouho považováno za podmínku svatosti křest’anských světců, ${ }^{58}$ Mesiáš musel trpět (Sk 17:3), protože Bůh ,tímto zpưsobem vyplnil, co předem ohlásil ústy všech prorokü“ (Sk 3:18), a všichni praví proroci byli vždy pronásledováni (Sk 7:52). Jako Ježǐšs, tak i apoštolové - včetně sv. Pavla (s výjimkou sv. Jana), sv. Barnabáše, sv. Jiří - a všichni nejvýznamnější čeští světci (Václav, Ludmila, Vojtěch a Jan Nepomucký) byli podle hagiografických legend umučeni pro svou víru: tedy „opakovali“ Ježíšův osud. Právě zde nacházím konceptuální kořeny onoho analogického osudu velkých českých skladatelů. Mučednictví a nepochopení ze strany současníků nacházíme ovšem i v Schopenhauerově a Nietzscheho koncepcích génia. Podle Schopenhauera žije génius zpravidla neštastný život a jeho „vnitřni trýzeñ je mateřským klínem nesmrtelných dél“; bývá nepochopen, protože neskutečně převyšuje „chápavost“ $\mathrm{i}$ „výkonnost" ostatních lidí a navíc bývá v „,rozporu a boji se svou dobou“, vrhaje „svá díla na dráhu běžici daleko vpřed [...], na niž je bude muset doba teprve dohonit ${ }^{\text {" }} .59$

Přestože není mým cílem v této studii detailně zkoumat dějinně-filosofické pozadí Nejedlého koncepce, rád bych zmínil ještě alespoň několik jejích pravděpodobných inspiračních zdrojů.

První, nejzjevnější a nejsilnější zdroj představuje zakladatelské dílo moderní české historiografie, Palackého Dějiny národu českého v Čechách a v Moravě. Zejména mám na mysli Palackého reprezentaci Jana Husa. Palacký popisuje Husa jako člověka ,prrisně opravdového a pevného charakteru“, největšího ducha své doby, ${ }^{60}$ oddaného velké myšlence jako pravý apoštol, jako spirituálního člověka, mučedníka, který ,nemaje voliti nežli mezi smrtí tělesnou a duchovní, volil si záhubu těla." "61 Palacký neváhal vylíčit Husovu skvělost za využití konceptů 19. století: Hus se stává géniem, vlastencem a pokrokářem. ${ }^{62}$ Pro Husa byla charakteristická:

„[...] prísná opravdovost ve všem jednání, mysl nábožná, víra živá i pevná, obcování i dle soudu neprátel bezouhonné, cit něžný ku přátelům, horlivá snaha o ušlechtěni národu a opraveni všeho, co v církvi tehdáž porušeného bylo,

58 DROBNER, Hubertus R. Patrologie: Úvod do studia starokrestanské literatury. Praha: Oikoymenh, 2011, s. 486.

59 SCHOPENHAUER, op. cit., s. 286-287.

60 PALACKÝ, František. Z Dějin národu českého. Praha: Státní nakladatelství krásné literatury, hudby a umění, 1957, s. 153 ff.

61 Ibid., s. 160.

62 Ibid., s. $156-158 \mathrm{ff}$. 
ale spolu také neobyčejná smělost, neustupnost a nešetrnost proti nepřátelům, do oka padajicí chtivost po lásce u lidu a po cti a slávě, ale slávě takové, která vrch svioj nalezá v koruně mučenické. [...] Vynikaltě mezi kolegami svými nejen silou charakteru, ale rozsáhlou zběhlostív oboru všech nauk souvěkých." ${ }^{\text {“63 }}$

V podstatě všechny povahové vlastnosti Velkého českého skladatele a jejich kombinace, stejně jako onu ambivalenci mužnosti a jemnosti nacházíme v Palackého líčení Husa. Palacký samozřejmě též zmiňuje Husovo následováni př́kla$d u$ trpících apoštolů a korunuje jím vyvrcholení celého Husova př́běhu: „,Hus] osvědčoval ochotnost svou podnikati všeliké muky za př́kladem, jak pravil, Kristovým $i$ apoštolìv jeho. “64 Podle Jiř́ho Křest’ana Nejedlý obdivoval Palackého Dějiny, Palacký pro něj byl ,jeden z hlavních Mistrů, [...] hned vedle Smetany““. ${ }^{65}$ Už jako gymnaziální student Nejedlý nadšeně četl Husovy spisy, což jej přivedlo ke studiu Bible a textů křest’anské věrouky; dokonce prý uvažoval o studiu na teologické fakultě (sic!), a v důsledku toho pak „,biblickou a náboženskou symboli$k u[\ldots]$ rád používal ve svých spisech" ${ }^{66}$

Nejedlý se též zjevně inspiroval samotnou rudimentárně křest'anskou obrazností a texty křest'anské věrouky. Jak naznačuje Jiří Křest'an, ${ }^{67}$ Nejedlý znal velmi dobře díla křest'anských otců, obdivoval Husa, a Ježíše považoval za ztělesnění dokonalého člověka. Po detailním prozkoumání Nejedlého textů připojuji, že Nejedlého vztah ke křest’anství se zdá být mnohem komplikovanější, než se běžně soudí. A to i navzdory jeho explicitně proklamovanému ateismu, míněnému mnohem spíše jako antiklerikalismus; ten byl široce rozšířený mezi dobovou českou inteligencí, Nejedlého duchovního vůdce Masaryka nevyjímaje. ${ }^{68}$ Ve své foersterovské monografii Nejedlý např. píše:

„Nejvyšším projevem ryzí lidskosti jest nám dosud duch pravého, prvniho křest'anství, ne církevního, formalitního křest'anství, nýbrž onoho ryze lidského křest’anství, jež k nám mluví z evangelia a prvnich legend. Jest v něm tolik krásy lidské čistoty a hloubky lidského ducha, že ještě dnes chví se jimi dušse často největš̌ich uměleckých géniư, toužicích po vytvoření pravého člověka. Sám obraz Kristův jest symbolem, nad nějž právě nejlidštější morálka dnešního světa nezná úchvatnějšiho. Ryzí člověk, tak ryzi že se nám ani nezdá býti člověkem; [...] Cítíme s ním a čím více s ním cítíme, tím lidštějèsi se nám zdá býti, on i jeho svět. Staré umění oslavovalo $v$ Kristu predevším metafysického boha, dnešni uměni naopak čistého

\footnotetext{
63 Ibid., s. 155.

64 Ibid., s. 162.

65 KŘESŤAN, Zdeněk Nejedlý, op. cit., s. 27. Srov. STŘíTECKÝ - HANZAL, Předmluva, op. cit., s. 6-9.

66 KřESŤAN, Zdeněk Nejedlý, op. cit., s. 28.

67 Ibid., s. 28-42.

68 Viz STŘíTECKÝ - HANZAL, Předmluva, op. cit., s. 15 ff.
} 
člověka, vznášejiciho se svým lidstvím až ke stupni boha-člověka. Odtud i jeho legendy jsou nám tak lidsky blizky. “"69

Druhý hlavní Nejedlého inspirační podnět musíme tedy hledat $\mathrm{v}$ jeho obdivu k prvotnímu, „neklerikálnímu“ křest’anství a české reformační tradici stejně jako v jeho představě Ježíše coby dokonalého člověka.

Předobraz Nejedlého Smetany nacházíme též v Masarykově České otázce, knize mající zásadní význam pro mladé intelektuály Nejedlého generace, konkrétně v Masarykově líčení Karla Havlička. ${ }^{70}$

Co se týče povahových vlastností, Havlíčkovi byla vlastní „opravdovost $v$ uměrenosti“, „opravdovost a ryzost presvědčeni“, „znal jasněji než kdo jiný svi̊j cil";; byl to člověk mužný, pokrokový, svobodomyslný, bojující ,proti duchovní reakci“", „člověk věcí a prítomnosti, člověk moderní, pokrokoví", „člověk přitomnosti, vlastně budoucnosti“", „člověk opravdovy““, vyznačující se „mužnou di̊slednosti“. Havlíčka i jeho umění Masaryk označuje adjektivy „český, lidový, realisticky" (protože ,nebyl od života odvráceny").

Jako Nejedlého slovník, tak i ten Masarykův má výrazně quasi-religiózní charakter: píše o Havlíčkově ,posláni" a ,požehnané“" práci; Havlíček „posvětil všecek sviuj život vzkříšení [...] národnosti a jazyka českého. Jeho víru ve věc českou nedokazuji pouze jeho plamenná věrná slova“.

Podobně jako Nejedlého Smetana i Masarykův Havlíček má v sobě imanentní českost, jež podmiňuje ryzí českost veškerého jeho konání: Havlíček „především cití česky, je Čech“, je „člověk naskrze český". Masarykovi je Havlíček největším Čechem a vzorem, „,národním vưdcem“, jenž „stál na stráźi národni““; ,[...] přestože měl rozhled světový a stopoval vývoj evropský, stačil mu vlastní národ“. Píše též o Havlíčkově ,posláni"“ a „mučednictvi“. Masaryk popisuje Havlíčka jako člověka v zásadě duchovně založeného, neustále přemítajícího o ,posledních věcech člověka“, a uzavírá tvrzením, že „,kdo Havlíčka po této stránce nepochopil, nepochopil ho vủbec a nepochopil smyslu české historie a českého ducha." Ano: tak jako Nejedlý vysvětluje smysl dějin české moderní hudby prostřednictvím Smetany, tedy vysvětluje je jakožto dějiny smetanovské, činí tak i Masaryk s českými moderními dějinami coby dějinami havlíčkovskými.

Nejedlého reprezentace historického pole je prŕkladem tzv. ,great man approach“, široce rozšířeného v 19. století v obecné historiografii i dějepisectví jednotlivých umění: historie je $\mathrm{v}$ zásadě reprezentována jako série životopisů velkých mužů, hrdinů, kteř́ hýbou dějinami. ${ }^{71}$ Thomas Carlyle, hlavní teoretik tohoto

69 NEJEDLÝ, Jos. B. Foerster, op. cit., s. 49.

70 MASARYK, Tomáš Garrigue. Česká otázka: Snahy a tužby národního obrození. / Naše nynějši krise: Pád strany staročeské a počátkové směrů nových. Praha: Čin, 1948, s. 102-105. Zvýraznil M. Z. Česká otázka vyšla poprvé v roce 1895, přesně v době, kdy se pravděpodobně počínala rodit Nejedlého koncepce, plně pak př́tomná už ve fibichovské monografii $\mathrm{z}$ roku 1901.

71 Viz GRININ, Leonid. The Role of an Individual in History: A Reconsideration. Social Evolution and History, 2010, roč. 9, č. 2, s. 95-136. „Great man approach“ může být chápán jako 
prístupu, považoval proroka nebo světce za typický prototyp velkého muže. ${ }^{72}$ Kněz nebo prorok je „light of inspiration“, „enlightener of daily life“, zvěstovatel svatosti, duchovní vůdce lidu, moudře jej směřující k nebi. Podle Carlyla je ideál hrdiny-proroka, jenž nabývá různých forem $\mathrm{v}$ průběhu historie, věčně platný. ${ }^{73}$ Podobně Nietzsche odhaluje religiózní rozměr lidského toužení po géniovi coby antropologické konstanty. Celou kulturu podle něj provází touha člověka „být znovuzrozen jako génius“, touha hř́šníka po svatosti. ${ }^{74}$ „Nebot' génius plane touhou po svatosti, jelikož ze své výše vidí dál a jasněji než jiní lidé, shliží do hloub$k y$, $v$ niž vládne mír mezi poznáním a bytím, nahliži do ríše míru a popřené vůle, vzhliži $k$ druhému břehu ${ }^{\text {" }}{ }^{75}$ Nejedlého zde analyzované texty dohromady vytvářejí jakousi hagiografii, založenou na podobné koncepci skladatele jako hrdiny a proroka.

V samém závěru této studie bych rád stručně vysvětlil rétorický a ideologický mechanismus Nejedlého narativu, využívajícího výše analyzovanou koncepci společných povahových vlastností, společného ducha a osudu. Mechanismus funguje následovně: (1) Čtenář na základě syžetů Nejedlého textů konstruuje $f a$ buli ${ }^{76}$ a odhaluje (at' už vědomě, či podvědomě) paralely mezi touto fabulí a velkými př́iběhy křest’anské mytologie, zejména toho o Ježíši a apoštolech. Na základě nastíněné adekvace čtenár rozpoznává společný osud velkých českých skladatelů a jeho prototyp, pocházející z křest’anské mytologie. (2) Čtenáŕ Evangelií a Skutků rekonstruuje - nebo je přinejmenším veden k tomu, aby rekonstruoval - obraz modelového, ideálního křest'ana, jeho povahových vlastností, atd. Podobným způsobem je čtenáŕ Nejedlého textů systematicky veden $\mathrm{k}$ tomu, aby rekonstruoval obraz ideálního českého skladatele a identifikoval onu skupinu povahových vlastností, která spojuje velké české skladatele a odlišuje je od ostat-

podtyp toho, co Burke nazývá „pohled seshora“; podle Burkeho se jedná o jednu z hlavních charakteristik ,tradični historie“, jež ,se vždy soustředí na velké činy velkých mužů, státnikưu, generálů a príležitostně též kněžl". BURKE, Peter. Overture. The New History: Its Past and Its Future. In New Perspectives on Historical Writing. Peter Burke (ed.). Cambridge: Polity Press, 2001, s. 4. Přeložil M. Z.

72 Carlyle Napsal: ,[...] all sorts of heroes are intrinsically of the same material; that given a great soul, open to the divine significance of life, then there is given a man fit to speak of this, to sing of this, to fight and work for this, in a great, victorious, enduring manner; there is given a hero - the outward shape of whom will depend on the time and the environment he finds himself in." CARLYLE, Thomas. Heroes and Hero Worship. In Thomas Carlyle. The Best Known Works of Thomas Carlyle: Including Sator Resartus, Heroes and Hero Worship and Characteristics. Rockville: Wildside Press, 2010, s. 229.

73 CARLYLE, Thomas. On Heroes, Hero-Worship and the Heroic in History. New York: Frederick A. Stokes and Brother, 1888, s. 128-129.

74 NIETZSCHE, op. cit., s. 167.

75 Ibid., s. 168.

76 Zde použivám dichotomii „syžet“ a „fabule“ ve smyslu ustaveném ruskými formalisty; pojem „fabule“ znamená příběh v „syrovém“ stavu, ve své základní, lineární formě, „syžet“ pak znamená konkrétní temporální podobu fabule; viz např. TOMAŠEVSKIJ, Boris V. Teorie literatury. Praha: Lidové nakladatelství, 1970, s. 127-128. 
ních. (3) Potom není pro modelového čtenáře Nejedlého textů nic jednoduššího, než nalézt adekvaci mezi těmito dvěma koncepty ideálního člověka, tak jako je pro modelového čtenáře Dostojevského Idiota (jedné z knih, kterou žili čeští intelektuálové Nejedlého generace) docela snadné rozpoznat adekvaci mezi postavou knížete Myškina a postavou Ježíše. Následně na základě kulturně zděděné znalosti biblické mytologie, rétoriky a biblických poetických praktik Nejedlého čtenáŕ (vědomě i podvědomě) ztotožní komplexní model Velkého českého skladatele s modelem křest’anského světce a odhaluje paralely mezi Smetanou a Ježíšem a mezi Smetanovými pokračovateli a apoštoly. (4) Vlivem této převážně podvědomé identifikace paralel mezi zjevnou rovinou Nejedlého narativu a jeho strukturními prototypy čtenář podléhá ideologii Nejedlého diskurzu, poněvadž se mu zdá důvěryhodnější a „logičtější" než jeho možné alternativy. Emoce vítězí nad kritickým rozumem a historie moderní české hudby získává svůj smysl. ${ }^{77}$

Miloš Zapletal (M.Zapletal1987@gmail.com), Ústav hudební vědy, Filozofická fakulta, Masarykova univerzita, Brno; Kabinet hudební historie, Etnologický ústav, AV ČR, Praha, CZ.

\section{ABSTRACT \\ BETWEEN GENIUS AND SAINT: DECONSTRUCTION OF NEJEDLÝ'S CONCEPTION OF THE GREAT CZECH COMPOSER}

Based on a previous metahistorical analysis of Zdeněk Nejedlýs conception of the history of modern Czech music, as it is revealed in his main texts from the period 1901-1921, the paper presents results of a deconstruction of Nejedly's conception of the Great Czech Composer. This conception is based on concepts of common ideal character traits, common martyr-like destiny, and common Smetanian or Bohemian spirit, shared by all great Czech composers (Smetana, Fibich, Foerster). Its narrative mechanism used systematic referring to the conception of an ideal Christian saint and was probably also influenced or transmitted by the essential $19^{\text {th }}$ century conceptions of genius (Kant, Schopenhauer, Nietzsche) as well as by representations of great personae of Czech history (Jan Hus, Karel Havlíček) in two important texts of the Czech philosophy of history F. Palacký's History of the Czech Nation and T. G. Masaryk's Czech Question.

\section{Key words}

Zdeněk Nejedlý, historiographical conceptions, philosophy of history, history of the modern Czech music, deconstruction, metahistory, discourse analysis, cultural materialism, methodologies of the writing of music history

\section{Bibliography}

BECKERMAN, Michael B. New Worlds of Dvorák: Searching in America for the Composer's Inner Life. New York, London: W. W. Norton \& Company, 2003.

BERKHOF, Louis. Dějiny dogmatu. Praha: Návrat domů, 2003.

77 Rád bych poděkoval prof. Miloši Štědroňovi za cenné rady a připomínky. 
BROWN, Julie. Understanding Schoenberg as Christ. In The Oxford Handbook of the New Cultural History of Music. Jane F. Fulcher (ed.). Oxford: Oxford University Press, 2011, s. 117-162.

CAMPBELL, Joseph. The Masks of God: Occidental Mythology. New York: Penguin Books, 1991.

CARLYLE, Thomas. On Heroes, Hero-Worship and the Heroic in History. New York: Frederick A. Stokes and Brother, 1888.

CARLYLE, Thomas. The Best Known Works of Thomas Carlyle: Including Sator Resartus, Heroes and Hero Worship and Characteristics. Rockville: Wildside Press, 2010.

ČINÁTL, Kamil. Dějiny a vyprávění. Palackého dějiny jako zdroj historické obraznosti národa. Praha: Argo, 2011.

ČORNEJ, Petr. White nezměnil dějiny, ale pohled na ně. In Hayden White. Metahistorie. Historická imaginace v Evropé devatenáctého století. Brno: Host, 2011, s. 575-600.

DeNORA, Tia. Beethoven and the Construction of Genius: Musical Politics in Vienna, 1792-1803. Berkeley and Los Angeles: University of California Press, 1995.

DROBNER, Hubertus R. Patrologie: Úvod do studia starokřestanské literatury. Praha: Oikoymenh, 2011.

FEUEREIS, Eduard. Narativismus a historiografie. Dějiny - teorie - kritika, 2011, roč. 8, č. 1, s. 7-34.

FOUCAULT, Michel. Diskurs, autor, genealogie: 3 studie. Praha: Svoboda, 1994.

Genius: The History of an Idea. Penelope Murray (ed.). London: Blackwell, 1989.

GRININ, Leonid. The Role of an Individual in History: A Reconsideration. Social Evolution and History, 2010, roč. 9, č. 2, s. 95-136.

HOSTINSKÝ, Otakar. Bedřich Smetana a jeho boj o moderní českou hudbu. Praha: J. Laichter, 1901.

KANT, Immanuel. Kritika soudnosti. Přel. V. Špalek a W. Hansel. Praha: Odeon, 1975.

KERMAN, Joseph. How We Got into Analysis, and How to Get out. Critical Inquiry, 1980, roč. 7 , č. 2, s. 311-331.

KIERKEGAARD, Søren. Má literárni činnost. Přel. Marie Mikulová Thulstrupová. Brno: Centrum pro studium demokracie a kultury, 2003.

KŘESŤAN, Zdeněk. Pojetí české otázky v díle Zdeňka Nejedlého. Praha: Státní úřední archiv, 1996.

KŘESŤAN, Zdeněk. Zdeněk Nejedlý. Politik a vědec v osamění. Praha - Litomyšl: Paseka, 2012.

LÉBL, Vladimír - POLEDŇÁK, Ivan (eds.). Hudební věda: Historie a teorie oboru, jeho světový a český vývoj - 1. díl. Praha: Státní pedagogické nakladatelství, 1988.

LUKÁCS, György. The Historical Novel. London: Merlin, 1962.

MACURA, Vladimír. Český sen. Praha: Nakladatelství Lidové noviny, 1998.

MASARYKOVÁ-GARRIGUE, Charlotte. O Bedřichu Smetanovi. Praha: Sbor pro postavení pomníku B. S., 1930.

MASARYK, Tomáš Garrigue. Česká otázka: Snahy a tužby národního obrození. / Naše nynějši krise: Pád strany staročeské a počátkové směrů nových. Praha: Čin, 1948

MAUS, Fred Everett. Concepts of Musical Unity. In Rethinking Music. Nicholas Cook - Mark Everist (eds.). Oxford: Oxford University Press, s. 171-192.

NEJEDLÝ, Zdeněk. Zdenko Fibich. Zakladatel scénického melodramatu. Praha: Hejda a Tuček, 1901.

NEJEDLÝ, Zdeněk. Dějiny české hudby. Praha: Hejda a Tuček, 1903.

NEJEDLÝ, Zdeněk. Antonín Dvořák mrtev. Zvon, 1904, roč. 4, č. 33, s. 464.

NEJEDLÝ, Zdeněk. Ke sporu o K. Knittla: na obranu K. Steckerovi. Praha: Jos. Pávek, 1907.

NEJEDLÝ, Zdeněk. Zpěvohry Smetanovy. Praha: J. Otto, 1908.

NEJEDLÝ, Zdeněk. Jos. B. Foerster. Praha: Komorní hudební závod Mojmíra Urbánka, 1910.

NEJEDLÝ, Zdeněk. Česká moderní zpěvohra po Smetanovi: kurs šestnáctipřednáškový. Praha: J. Otto, 1911.

NEJEDLÝ, Zdeněk. Slovanská hudba. In Slovanstvo: obraz jeho minulosti a přitomnosti. Jaroslav Bidlo (ed.). Praha: J. Laichter, 1912, s. 606-626. 
NEJEDLÝ, Zdeněk. „Boj“ proti Ant. Dvořákovi. Česká kultura, 1912/1913, roč. 1, č. 6, s. 187.

NEJEDLÝ, Zdeněk. Vitězslav Novák. Studie a kritiky. Praha: Melantrich, 1921.

NEJEDLÝ, Zdeněk. Smetaniana. Praha: Melantrich, 1922.

New Perspectives on Historical Writing. Peter Burke (ed.). Cambridge: Polity Press, 2001.

NIETZSCHE, Friedrich. Nečasové úvahy. Přel. Jan Krejčí a Pavel Kouba. Praha: OIKOYMENH, 2005.

Odvaha být církví. Josef Zvěřina v letech 1913-1967. Vojtěch Novotný (ed.). Praha: Karolinum, 2013.

PALACKÝ, František. Z Dějin národu českého. Praha: Státní nakladatelství krásné literatury, hudby a umění, 1957.

PEČMAN, Rudolf. Útok na Antonína Dvořáka. Brno: Filozofická fakulta Masarykovy univerzity, 1992.

Poetika rytmus verš. Jurij Lotman (ed.). Praha: Svět sovětů, 1968.

PROPP, Vladimir Jakovlevič. Morfologie pohádky a jiné studie. Jinočany: H \& H, 2008.

RANSDORF, Miloslav. Zdeněk Nejedlý. Praha: Horizont, 1988.

ŘEPA, Milan. Poetika českého dějepisectví. Brno: Host, 2006.

SCHOPENHAUER, Arthur. Svět jako vůle a predstava. Svazek II. Přel. M. Váňa. Pelhřimov: NTP, 1998.

STŘÍTECKÝ, Jaroslav - HANZAL, Josef. Předmluva. In Zdeněk Nejedlý. Uměni staré a nové: Výbor ze studií. Praha: Editio Supraphon, 1978, s. 5-37.

TOMAŠEVSKIJ, Boris V. Teorie literatury. Praha: Lidové nakladatelství, 1970.

TYRRELL, John. Czech Opera. Cambridge: Cambridge University Press, 1988.

WAGNER, Richard. Das Kunstwerk der Zukunft. Leipzig: Otto Wigand, 1850.

WAGNER, Richard. Ein deutscher Musiker in Paris. Novellen und Aufsätze. Leipzig: Insel-Verlag, 1914.

WHITE, Hayden. Metahistory. The Historical Imagination in Nineteenth-Century Europe. Baltimore: Johns Hopkins University Press, 1973.

WHITE, Hayden. Tropics of Discourse: Essays in Cultural Criticism. Baltimore: Johns Hopkins University Press, 1978. 
